\title{
ANALYSIS OF FISHING PORTS TO SUPPORT THE DEVELOPMENT OF TUNA FISHERIES IN THE SOUTH COAST OF JAVA
}

\author{
Tri Wiji Nurani"), Ernani Lubis ${ }^{1)}$, John Haluan"1, and Sudirman Saad ${ }^{2)}$ \\ ${ }^{1)}$ Lecturer in Faculty of Fisheries and Marine Science, Bogor Agricultural University, Bogor \\ ${ }^{2)}$ Secretary of the Directorate General of Coastal and Small Island, Ministry of Marine Affairs and Fisheries \\ Received February 1-2010; Received in revised form July 1-2010; Accepted October 6-2010
}

\begin{abstract}
Construction of a fishing port requires special conditions to be properly developed. The right choice of location from the land and water aspects is the basic requirement to build a fishing port facilities. The location of the fishing port requires the nearest location with the fishing ground for cost efficiency of fishing operation and accessibility of supply, distribution, marketing, and communication to the outside world. The fishing port for tuna fisheries has more specific characteristics compared to fishing ports for other fisheries. The objective of the research was to determine the suitable location for the development of tuna fisheries in the South Coast of Java. The research was conducted by evaluating some fishing ports and fish landing stations (PP/PPIs) in the South Coast of Java based on three aspects, i. e. inter relation with the fishing ground (forward linkages), technical aspects of the fishing port, and market accessibility (backward linkages). The result showed that Pelabuhan Perikanan Samudera Cilacap and Pelabuhan Perikanan Nusantara Pelabuhan Ratu could provide more than $50 \%$ of the inter relation with the fishing ground. From the technical aspects of the fishing port, Pelabuhan Perikanan Samudera Cilacap, Pelabuhan Perikanan Nusantara Pelabuhan Ratu, and Pelabuhan Perikanan Nusantara Prigi could provide more than $50 \%$. In general, Pelabuhan Perikanan Samudera Cilacap and Pelabuhan Perikanan Nusantara Pelabuhan Ratu are the fishing ports to be recommended for the development of tuna fisheries in the South Coast of Java.
\end{abstract}

\section{KEYWORDS: $\quad$ fishing port, forward/backward linkages, tuna fisheries, South Coast of Java}

\section{INTRODUCTION}

Fishing port has a strategic roles in developing fisheries sector in a region. Furthermore fishing port also has a function to support infrastructures to increase work performances, i.e. as a community development center for fishermen, as a berthing place for fishing boats, as fish landing station, as a center of distribution and marketing, as a center of skilled development, guidance and data collection (Explanation of Law No.31/2004 j.o. No.45/2009 regarding Fisheries).

The construction of a fishing port requires special conditions for the fishing port itself to develop. The feasibility of land and water aspects is the main condition to build a fishing port facilities. The location of the fishing port requires the nearest location with the fishing ground, one of the reasons is for cost efficiency of fishing operation. The location of the fishing port should also has the highest level of accessibility in order to smooth chains of supply, distribution, marketing, and communication with the outside world.

The sea of the South Coast of Java is widely knows as rich water with tuna which is needed to be managed and exploited sustainably. A model for developing of tuna fisheries in South Coast of Java has been investigated by Nurani et al. (2008). The model recommended that there are three subsystems which should be well managed in order to develop tuna fisheries in South Coast of Java, those are fisheries business subsystem, fishing port subsystem functionality and accessibility, and policy and fisheries institution subsystem.

This paper focuses on discussing fishing port subsystems including functionality and accessibility, by evaluating some fishing ports and fish landing stations (PP/PPIs) in the South Coast of Java to be recommended as the center of tuna fisheries development.

According to Vigarie (1979) referred to Lubis (1989), there are three components which should be observed in analyzing a public port i. e. avant pays marin (foreland), port de peche (fishing port), and arriere pays terrestre (hinterland) which are called tryptique portuaire. Furthermore according to Lubis (2006), geographically, in designing a port, an analysis of three elements should be conducted, i.e. analysis on foreland, analysis on the port itself, and analysis on hinterland.

The fishing ports which are needed as the basis of tuna fisheries has more specific characteristics compared to fishing ports for other fisheries. The big 
sizes of fishing vessels require wide port entrance, water depth, and adequate facilities. The main purpose of fresh tuna product requires appropriate handling facility and well access to the export destination ports. The research is aimed to determine the suitable fishing port which can support development of tuna fisheries in the South Coast of Java.

\section{MATERIALS AND METHODS}

\section{Time and Places of Research}

The research was conducted from July 2005 to July 2007. The places to be selected for the research were Pelabuhan Perikanan Nusantara Pelabuhan Ratu, Pelabuhan Perikanan Samudera Cilacap, Pelabuhan Perikanan Nusantara Prigi, Pelabuhan Perikanan Pantai Cilautereun, Pelabuhan Perikanan Pantai Pondokdadap, Pusat Pelelangan Ikan Pasir, Pusat Pelelangan Ikan Sadeng, and Pusat Pelelangan Ikan Tamperan (Figure 1).

\section{Data Collection}

The data collection was conducted through field surveys covering two activities, i. e. field observation and information from secondary data. The field observation covered:

1. Observation on the physical conditions of fishing ports and fish landing stations (PP/PPIs), including basic, functional and supporting facilities, accessibility to transportation facilities and supporting infrastructures such as telecommunication networks, fresh water supply and electricity.

2. Observation on the activities at the fishing ports, such as catch unloading, handling, auction, distribution, and marketing of the catching fish, fuel, fresh water, and other supplies loading, fishing boats, and fishermen's activities at the PP/PPIs.

The information from the secondary data was gathered from the government institutions, non government institutions and private sectors around the places where the research were conducted. The information collected from the secondary data covered site map, feasibility study of the PP/PPIs, and other secondary data related to the research.

\section{Data Analysis}

The data analysis is a meant to analyze the fishing port characteristics which are needed to support the development of tuna fisheries in the South Coast of Java. The analysis was conducted by evaluating the role of existing PP/PPIs to support tuna fisheries activities. The analysis covered (a) inter relation with the fishing ground (forward linkages), (b) technical aspect of the fishing port, and (c) market accessibility (backward linkages) adapted from Vigarie (1979); referred to Lubis (1989); Lubis (2006). 


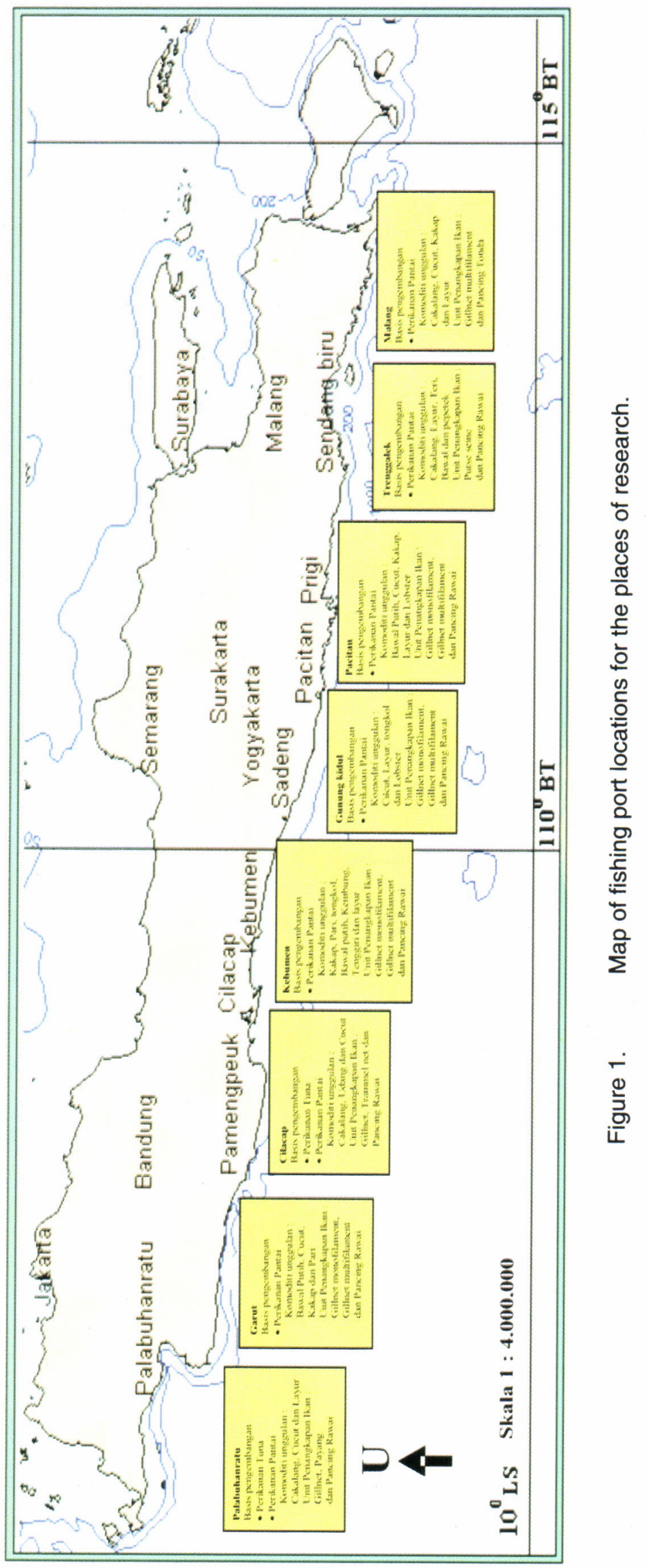




\section{Analysis of Inter Relation with the Fishing Ground (Forward Linkages)}

The inter relation with the fishing ground (forward linkages) is related with the efficiency of the use of production inputs, such as the use of fuel, and operational supplies. The analysis is related with its ability to attract longline vessels to unload their catch at the PP/PPIs. The attracting factors can be divided into three catagories, i. e. water facility, land facility, and market especially price determination facility. Diagram of descriptive analysis of inter relation with the fishing ground (forward linkages) is describe in Figure 2.

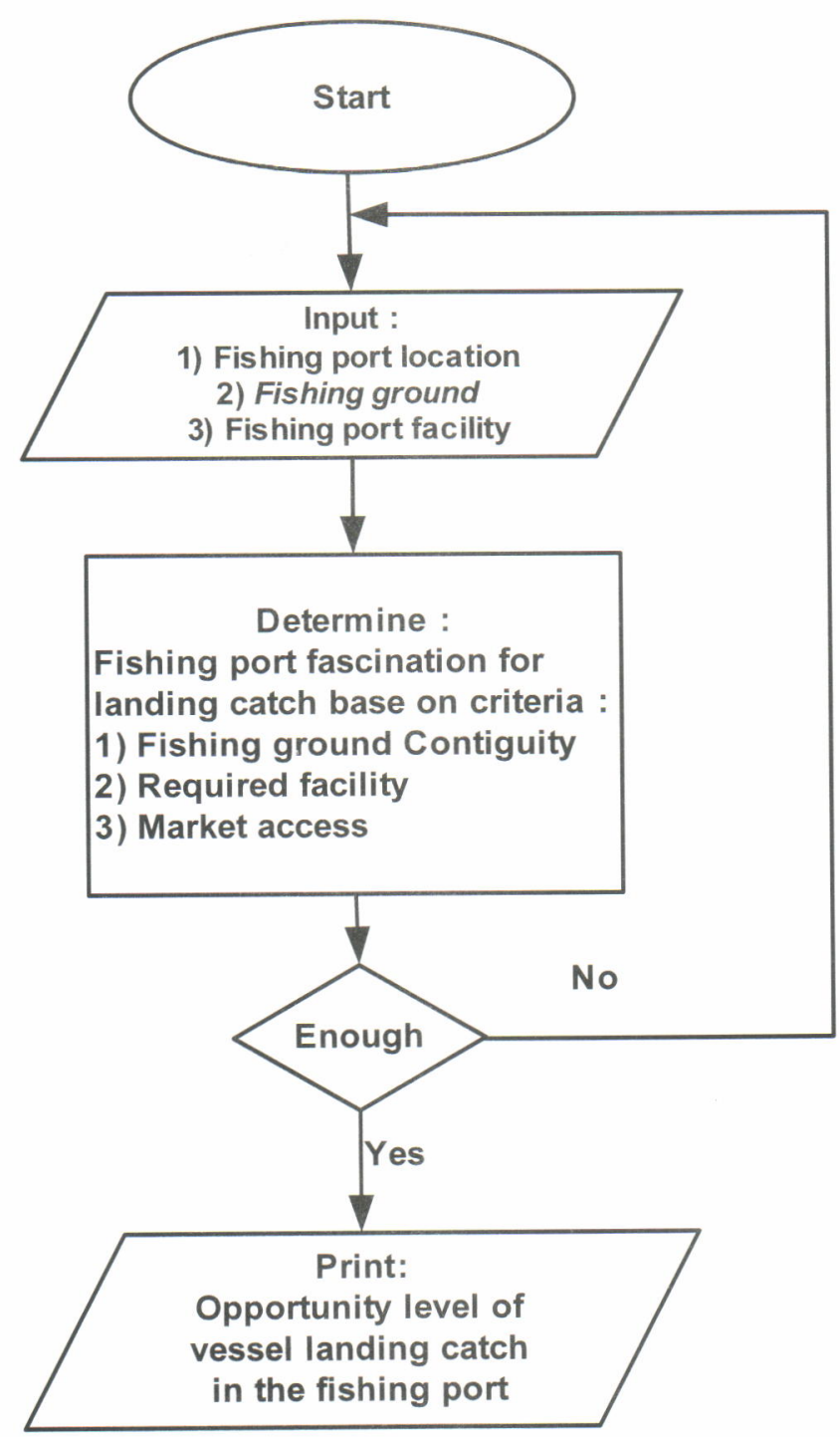

Figure 2. Descriptive flow diagram of inter relation with the fishing ground (forward linkages) analysis.

\section{Analysis of Technical Aspects of the Fishing Port}

The choice of location for the fishing ports should consider technical feasibility both from the land and water aspects. This is for the easiness in constructing the fishing port facilities such as port harbor, breakwater, piers, and other facilities. Diagram of descriptive analysis of technical aspects of the fishing port is describe in Figure 3. 


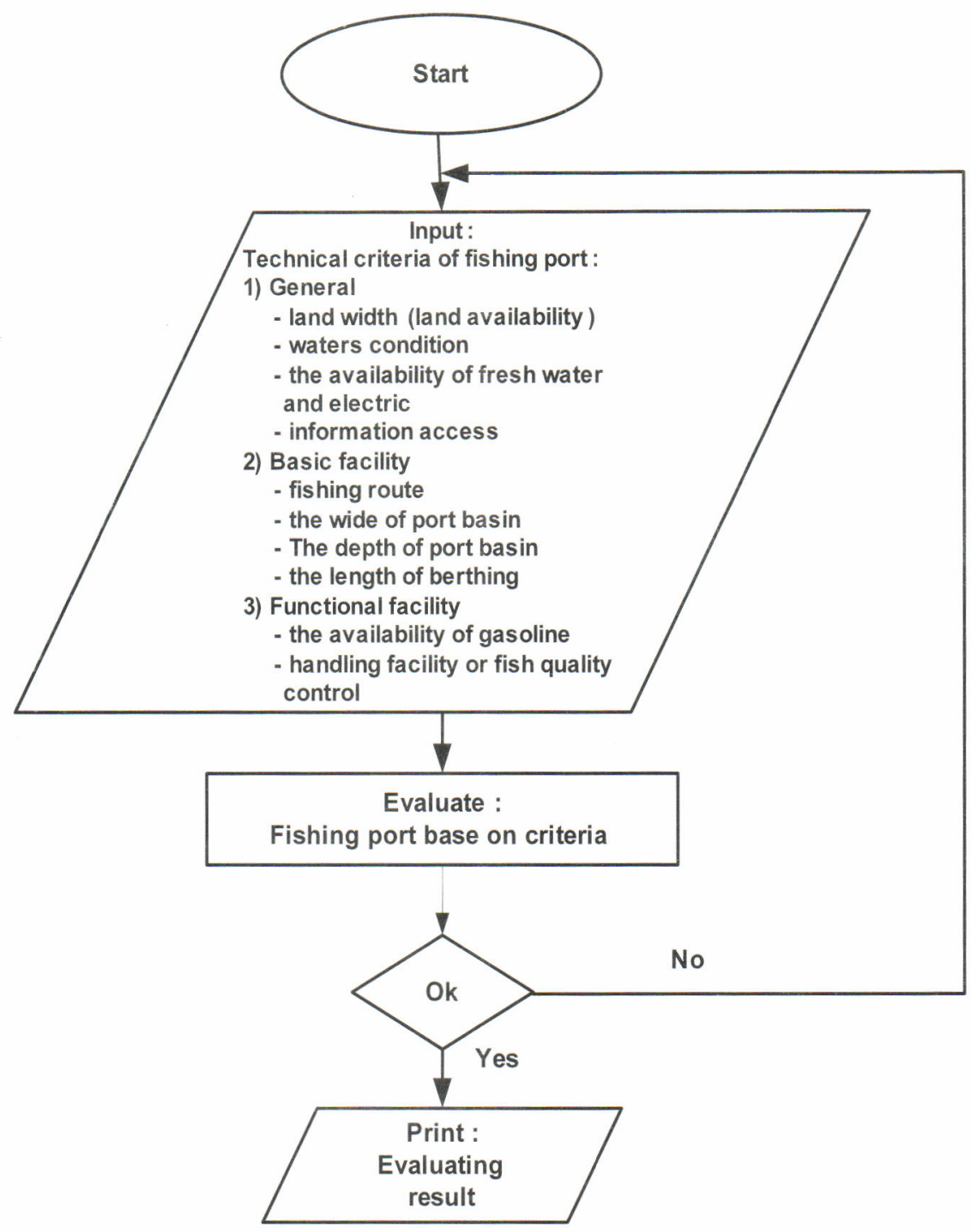

Figure 3. Descriptive flow diagram of technical aspect of the fishing port analysis.

\section{Analysis in Relation with the Market (Backward Linkages)}

The level of accessibility of fishing ports and fish landing stations (PP/PPIs) was analyzed by using a model developed by Tamin (2000). The accessibility of a location can be measured by pulling movements and rising movements model. The pulling movements and rising movements model are a function of land use. Number of pulling movements and the rising movements resulted from one zone is diametrically compared with the type and intensity of the land use in that zone:

$$
Q A=f(L A)
$$

where:

$$
\begin{aligned}
& Q A=\text { pulling riovement to zone } A \\
& L A=\text { land use in zone } A
\end{aligned}
$$

The same thing is also applied to rising movement:

$$
\mathrm{PA}=f(\mathrm{LA})
$$

where:

$$
\begin{aligned}
& \mathrm{PA}=\text { rising movement to zone } \mathrm{A} \\
& \mathrm{LA}=\text { land use in zone } \mathrm{A}
\end{aligned}
$$

Location accessibility could be increased by improving transportation infrastructure. The increase of the transportation infrastructure will be effective if it could increase mobility from PP/PPIs to the market or vice versa. The model of rising movements will 
predict the number of rising movements level in the future by studying various relationships between movement characteristics and the land use. The analysis was conducted by using the data based on the zone, such as the land use, vehicle ownership, population, number of workers, population density, and transportation modes (Tamin, 2000). Diagram of accessibility analysis and the rising movement is shown in Figure 4. All criteria which are used in analysis is presented in Table 1.

Table 1.

Criteria used for evaluating fishing port

\begin{tabular}{|c|c|c|c|c|c|}
\hline \multicolumn{2}{|c|}{$\begin{array}{l}\text { Inter relation with } \\
\text { fishing ground }\end{array}$} & \multicolumn{2}{|c|}{$\begin{array}{l}\text { Technical aspect of } \\
\text { fishing port }\end{array}$} & \multirow{2}{*}{$\begin{array}{l}\text { Accessibility } \\
\text { Criteria }\end{array}$} & \multirow{2}{*}{$\begin{array}{l}\text { Rising movement } \\
\text { Criteria }\end{array}$} \\
\hline Criteria & Sub criteria & Land aspect & Waters aspect & & \\
\hline Waters facilities & $\begin{array}{l}\text { The wide of } \\
\text { fishing route }\end{array}$ & Lands wide & Form of coastal & Distance & Land use \\
\hline & $\begin{array}{l}\text { The depth of } \\
\text { port basin }\end{array}$ & Loading facility & Fishing route & Time & $\begin{array}{l}\text { The number of } \\
\text { Society }\end{array}$ \\
\hline Land facilities & $\begin{array}{l}\text { Fish loading } \\
\text { facility }\end{array}$ & $\begin{array}{l}\text { Fish handling } \\
\text { facility }\end{array}$ & Berthing & Cost & $\begin{array}{l}\text { The growth of fishery } \\
\text { sector }\end{array}$ \\
\hline & $\begin{array}{l}\text { Provision } \\
\text { facility }\end{array}$ & & & $\begin{array}{l}\text { Transportation } \\
\text { facility }\end{array}$ & $\begin{array}{l}\text { The growth of in } \\
\text { dustrial sector }\end{array}$ \\
\hline Amenity potency & $\begin{array}{l}\text { Existence of } \\
\text { processing } \\
\text { industry }\end{array}$ & & & $\begin{array}{l}\text { Transportation } \\
\text { infrastructure }\end{array}$ & $\begin{array}{l}\text { The growth of } \\
\text { trading sector }\end{array}$ \\
\hline Marketing & $\begin{array}{l}\text { Existence of } \\
\text { exporter }\end{array}$ & & & $\begin{array}{l}\text { Journey } \\
\text { constraint }\end{array}$ & $\begin{array}{l}\text { The growth of } \\
\text { tourism sector } \\
\text { Existence of } \\
\text { government } \\
\text { centre }\end{array}$ \\
\hline
\end{tabular}

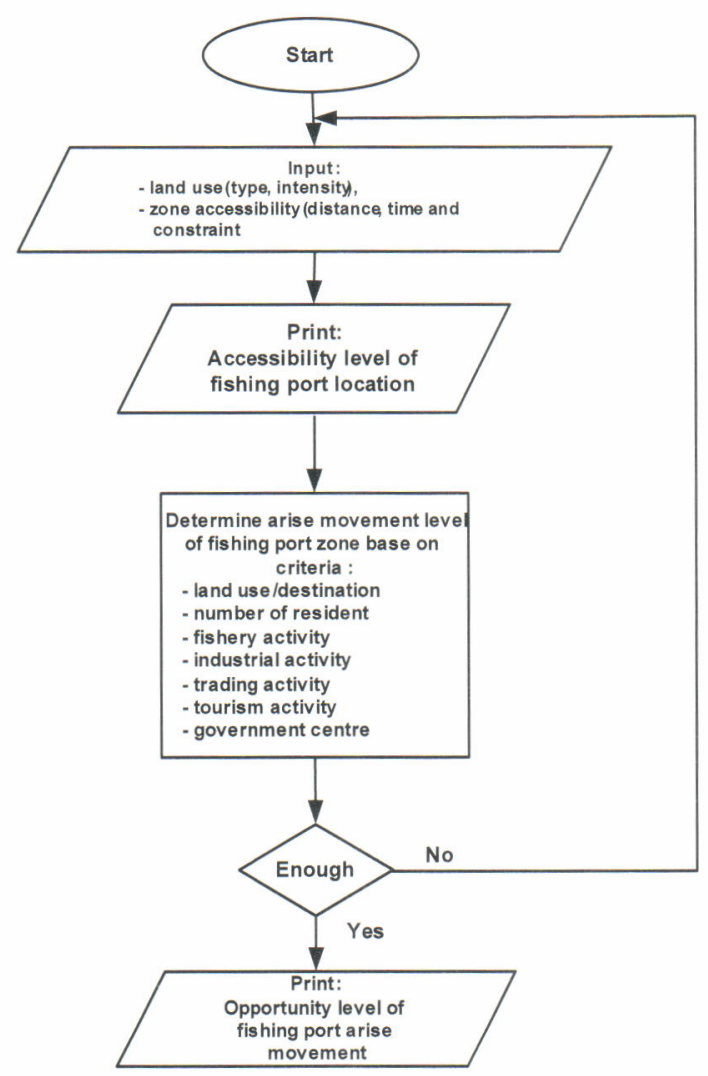

Figure 4. Descriptive flow diagram of market accessibility (backward linkages) analysis. 


\section{RESULTS AND DISCUSSION}

\section{Results}

\section{Inter Relation with the Fishing Ground}

The analysis result shows that Pelabuhan Perikanan Nusantara Pelabuhan Ratu and Pelabuhan Perikanan Samudera Cilacap were the most attractive place for the tuna longline vessels to stop by. However both Pelabuhan Perikanan Nusantara Pelabuhan Ratu and Pelabuhan Perikanan Samudera Cilacap did not comply $100 \%$ with the required criteria yet (Figure 5). This could be seen from the fact that only few long vessels stopped by at the both fishing ports. Most of long vessels preferred to stop by at Pelabuhan Perikanan Samudera Nizam Zachman, Jakarta or Benoa, Bali.

The less attractive point of Pelabuhan Perikanan Nusantara Palabuhanratu was lack of facility for handling fresh tuna product, such as transit sheed.
Another factor was lack of processing industry for tuna in Pelabuhan Ratu. Tuna was distributed by traders to Pelabuhan Perikanan Samudera Nizam Zachman, Jakarta to supply raw material for tuna processing industry. Direct export cannot be conducted from Pelabuhan Ratu unless through Soekarno-Hatta Airport.

\section{Technical Aspects of the Fishing Port}

The analysis result showed that the fishing ports which were technically feasible to be landed by the longline vessels were Pelabuhan Perikanan Nusantara Pelabuhan Ratu, Pelabuhan Perikanan Samudera Cilacap and Pelabuhan Perikanan Nusantara Prigi (Figure 5). According to technical point of view, the three fishing ports met the requirements for longline vessel landing. However, extension of capacity and some basic facilities should be added for the next development of tuna fisheries such as the width of the fishing ports and the length of the piers.

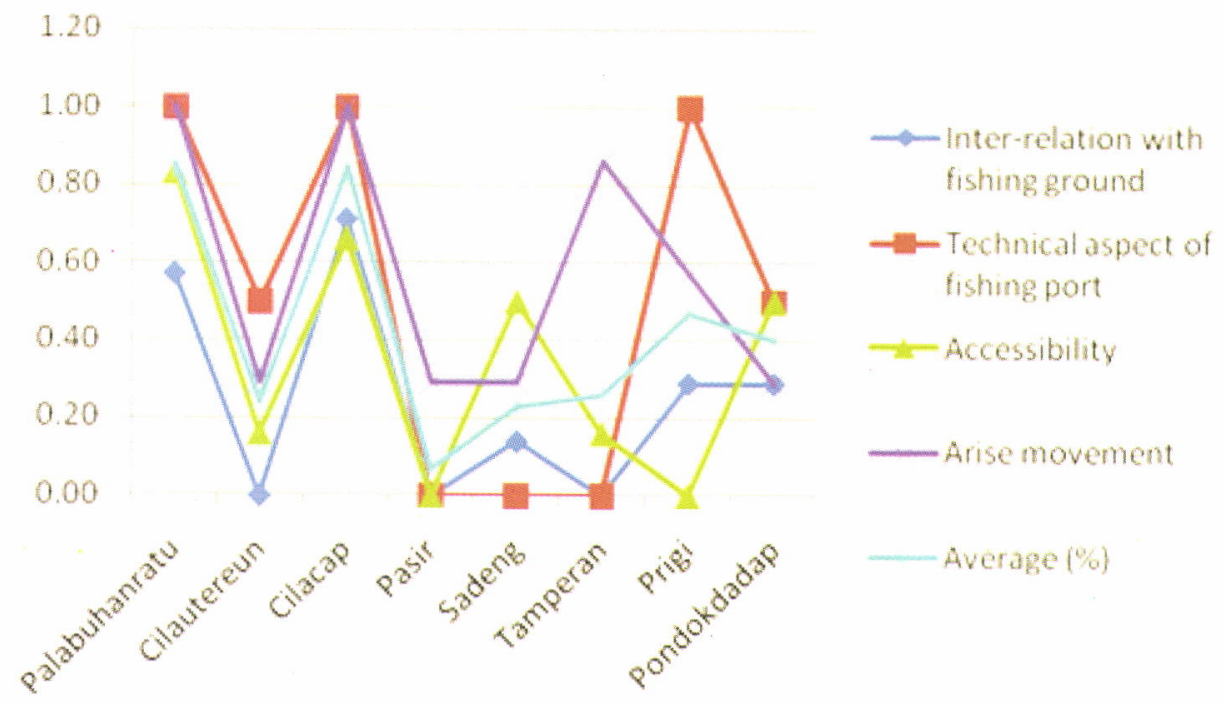

Figure 5. Evaluating result of accomplishment fishing port according to required criteria of fishing port.

Locations of Pelabuhan Perikanan Pantai Cilautereun, Pangkalan Pendaratan Ikan Pasir, Pangkalan Pendaratan Ikan Sadeng, Pangkalan Pendaratan Ikan Tamperan, and Pelabuhan Perikanan Pantai Pondokdadap were not feasible technically for landing longline vessels. The technical feasibilities of the four fishing ports were very low. For example, locations of Pangkalan Pendaratan Ikan Sadeng and Pelabuhan Perikanan Pantai Pondokdadap were not well protected from the threat of big wave. Both those fishing ports had narrowed land areas because of the hilly areas at the backside of the ports. Any developments of industrial areas have to flatten these hilly areas creating high cost and have to obtain permission from Perhutani (state owned forestry company) as these areas are under their authority. Locations of Pelabuhan Perikanan Pantai Cilautereun, Pangkalan Pendaratan Ikan Pasir and Pangkalan Pendaratan Ikan Tamperan did not really support for the development of tuna fisheries. Pelabuhan Perikanan Pantai Cilautereun, Pangkalan Pendaratan Ikan Pasir and Pangkalan Pendaratan Ikan Tamperan were located at the deltas which have high sedimentation level and unprotected. Therefore, development of those fishing ports for tuna fisheries will need huge investment. 


\section{Inter Relation with the Market}

Result of location accessibility analysis showed that only Pelabuhan Perikanan Nusantara Pelabuhan Ratu and Pelabuhan Perikanan Samudera Cilacap had the highest accessibility (Figure 5). Location of Pelabuhan Perikanan Nusantara Pelabuhan Ratu had the shortes distance and time as well as the lowest to reach the port for export, i. e. Soekarno-Hatta Airport, Jakarta. Road access to Pelabuhan Perikanan Nusantara Pelabuhan Ratu was quite good, but the road was steeping up and down. Transportation infrastructure to Pelabuhan Perikanan Samudera Cilacap was quite good and obstacles a long the way were relatively low, but had longer distance, lower cost, and longer travel time. Level of accessibility of Pelabuhan Perikanan Nusantara Prigi, Pelabuhan Perikanan Pantai Cilautereun, Pangkalan Pendaratan Ikan Pasir, Pangkalan Pendaratan Ikan Sadeng, and Pelabuhan Perikanan Pantai Pondokdadap were very low.

Analysis results of rising movement opportunity showed that zone locations of Pelabuhan Perikanan Nusantara Pelabuhan Ratu, Pelabuhan Perikanan Samudera Cilacap, Pangkalan Pendaratan Ikan Tamperan, and Pelabuhan Perikanan Nusantara Prigi have the highest rising movements opportunity (Figure 5). Due to the diverse land uses for fisheries sector, tourism, industry, and trading, developments of those sectors will give a big rising movements opportunity both for people and goods. High numbers of population in sub districts and city zone as the center of government will give a chance for the increase of mobility from and to the zone. Meanwhile, Pelabuhan Perikanan Pantai Cilautereun, Pangkalan Pendaratan Ikan Pasir, Pangkalan Pendaratan Ikan Sadeng, and Pelabuhan Perikanan Pantai Pondokdadap had lower rising movements opportunity.

\section{Overall Aspects}

Results from the analysis of inter relation with the fishing ground, port location and market, showed that only Pelabuhan Perikanan Nusantara Pelabuhan Ratu and Pelabuhan Perikanan Samudera Cilacap complied with required criteria for tuna fisheries development (Figure 5). Location of Pelabuhan Perikanan Nusantara Pelabuhan Ratu complied with the criteria, but high obstacle relating to the access did not meet the criteria. Location of Pelabuhan Perikanan Samudera Cilacap, in flows of inter relation with the market, did not complied with the criteria to be developed as tuna fisheries due to long distance to the port for export i. e. Soekarno-Hatta Airport inducing longer travel time and higher travel cost.

\section{Discussion}

The growth of fisheries activity is associated with the existence of the fishing port (Ismail, 2007). Not all PP/PPIs in the South Coast of Java were suitable for developing tuna fisheries. The analysis result showed that only Pelabuhan Perikanan Nusantara Pelabuhan Ratu and Pelabuhan Perikanan Samudera Cilacap could be developed for tuna fisheries in the South Coast of Java. Other fishing ports, such as Pelabuhan Perikanan Pantai Cilautereun, Pangkalan Pendaratan Ikan Pasir, Pangkalan Pendaratan Ikan Sadeng, Pangkalan Pendaratan Ikan Tamperan, Pelabuhan Perikanan Nusantara Prigi, and Pelabuhan Perikanan Pantai Pondokdadap demanded huge investment cost to be developed for tuna fisheries.

In relation to the location of the fishing port which is as the center of industrial activity, the geotopography is the most important aspect to consider. Most of the South Coast of Java areas are not strategic geotopographically for fishing industry activities. Isolated locations, with hilly, and steep slopes surfaces, insufficient roads, and transportation infrastructures are the potential obstacle factors for the development of fisheries industry in the areas. Location with high transportation cost is not efficient for fish product distribution to the market and potentially will increase production cost factors.

The geotopographical aspect is also related with the right choice of location for the development of fishing port. Location of fishing port requires a large and almost flattened land area. The large area is needed for construction of required facilities, such as fish auction place, nets drying place, fish processing place, workshop, ice factory, cold storage, parking lot, etc. (Murdiyanto, 2003). Flattened land surface condition will make easier for goods flow from one facility to another within the port. Of course, those facilities will be muin easier to be built in a flattened surface area compared to the hilly one.

Technically, a fishing port which is built in a naturally protected area needs less cost compared to one built in the open waters area. The breakwater will be much less constructed to save the cost of investment. Geological location of Indonesia which is vulnerable to the tsunami really need a protected area for the fishing port. Location of Pelabuhan Perikanan Samudera Cilacap has been proved to be protected from tsunami attacking the South Java waters in 2006. Ten fishing boats at Pelabuhan Perikanan Pantai Pasir were broken down during tsunami and some facilities at Pelabuhan Perikanan Pantai Sadeng were damaged. 
Although Pelabuhan Perikanan Nusantara Pelabuhan Ratu and Pelabuhan Perikanan Samudera Cilacap could support technically the development of tuna fisheries in the South Coast of Java, they could only meet $35 \%$ of the required conditions. Construction of facilities and increase of services at Pelabuhan Perikanan Nusantara Pelabuhan Ratu and Pelabuhan Perikanan Samudera Cilacap are needed in order to comply with the needs of the operations of longline vessels. The current condition, longline vessels were preferred to unload their catch at Pelabuhan Perikanan Samudera Nizam Zachman, Jakarta or Benoa, Bali. For the development of tuna fisheries, the both fishing ports are expected to be able to give quality assurance of exported tuna in accordance with the export quality standards. Implementation of good manufacturing practices or good handling practices and standard sanitation operational procedure are important to be implemented at the fishing ports.

Facilities for handling fresh tuna, such as tuna landing center and tuna processing industry at Pelabuhan Perikanan Nusantara Pelabuhan Ratu were not available. Tuna is exported through Soekarno-Hatta Airport by taking high risk of obstacle on the way to the airport. In order to support development of tuna fisheries, export is expected could be directly from Pelabuhan Ratu.

Cilacap fishing port complied with the required conditions to support the development of tuna fisheries in South Coast of Java, but there are some points to be considered. The existing facilities such as port harbor, port entrance, and piers were already built and suitable for landing longline vessels. The problem was the high level of sedimentation in the port entrance to making difficult for the longline vessels to enter the port harbor. This was one of the reasons why the numbers of longline vessels entering Pelabuhan Perikanan Samudera Cilacap dropped in 2003-2004. Suherman (2007) said, the decrease of production activities at Cilacap was caused by sedimentations at the port entrance and dredging and upgrading of port entrance were needed to overcome the problem.

Fresh tuna handling facility was available at Pelabuhan Perikanan Samudera Cilacap. The tuna landing center facility was already exist but not equipped with transit sheed. Tuna processing industry is already developed at Pelabuhan Perikanan Samudera Cilacap. Cilacap has a good road and transportation infrastructure and less obstacles on the way, but longer distance, higher cost, and more travel time to reach nearest airport for export. Export of fresh tuna through the Soekarno-Hatta Airport will cause more travel time and higher cost.
Development of tuna fisheries in the South Coast of Java requires an airport facility for export. District governments of Sukabumi and Cilacap have been planning to build airports in order to support development of tuna fisheries in their areas. District government of Cilacap is planning to develop Tunggul Wulung Airport to become an export port. If the plans can be realized, development of Pelabuhan Perikanan Samudera Cilacap and Pelabuhan Perikanan Nusantara Pelabuhan Ratu as the center of tuna fisheries in the South Coast of Java will be achieved.

Nurani et al. (2008) said optimum numbers of longlines to be allowed was 170 units. Increasing numbers of longlines will require increasing facilities of the port, such as the facilities which should be improved are the depth of the harbor and the width of the port entrance to be about 6.20-7.40 $\mathrm{m}$ and 43.44$57.92 \mathrm{~m}$ respectively. Increasing of diesel oil supply, baits, ice and fresh water, is to be approximately $24,000 \mathrm{~kg}, 1,920$ tons, 336,000 blocks, and 840,000 $\mathrm{M}^{3}$. Apart from that, about 2,400 crews were needed. The compliance of the needs could be directed into two ports, i. e. Pelabuhan Perikanan Nusantara Pelabuhan Ratu and Pelabuhan Perikanan Samudera Cilacap, with the assumption Pelabuhan Perikanan Nusantara Pelabuhan Ratu is developed into fishing port type A. The development of Pelabuhan Perikanan Nusantara Pelabuhan Ratu into type A had been discussed in a meeting between Directorate General of Marine Fisheries, Ministry of Marine Affairs, and Fisheries with West Java Governor in October 2005 (Mahyuddin, 2007).

\section{CONCLUSIONS}

1. The research result showed that not all fishing ports or landing fish stations in the South Coast of Java can be developed to support development of tuna fisheries

2. Based on the attractiveness of the fishing vessels to stop by, Pelabuhan Perikanan Samudera Cilacap and Pelabuhan Perikanan Nusantara Pelabuhan Ratu complied more than $50 \%$ from the required criteria.

3. While from the technical aspects, Pelabuhan Perikanan Samudera Cilacap, Pelabuhan Perikanan Nusantara Pelabuhan Ratu and Pelabuhan Perikanan Nusantara Prigi could comply more than $50 \%$ of required criteria, both from the land and water aspects.

4. The fishing ports which have high accessibility and high rising movement opportunity in the future were 
Pelabuhan Perikanan Samudera Cilacap, Pelabuhan Perikanan Nusantara Pelabuhan Ratu and Pangkalan Pendaratan Ikan Tamperan.

5. In overall, the analysis results conclude that Pelabuhan Perikanan Samudera Cilacap and Pelabuhan Perikanan Nusantara Pelabuhan Ratu were the fishing ports which were recommended to support the development of tuna fisheries in the South Coast of Java.

\section{SUGGESTIONS}

In constructing a fishing port, a feasibility study should be properly conducted based on forward linkages approach, technical aspects, and backward linkages approach. The development of a fishing port is not merely for the interest of one region or area. For the development of tuna fisheries in the South Coast of Java, it is not necessary to build a fishing port in each province, but it would be enough to develop facilities and services at Pelabuhan Perikanan Samudera Cilacap and Pelabuhan Perikanan Nusantara Pelabuhan Ratu.

\section{ACKNOWLEDGEMENTS}

This study is regional fisheries development focusing on specifik local potency in 2004-2006 funded by BPPS/DEPDIKNAS.

\section{REFERENCES}

Ismail, 1. 2007. Planning development of fishing port and fish landing place in Indonesia, especially Java Island in decentralization era. In Lubis, E. \& A. B. Pane (eds). International Seminar Proceeding Dynamic Revitalisation of Java Fishing Port and Capture Finseries on Promoting the Indonesian
Fishery Development. PK2TM-LPPM IPB and Geolittomer-CRNS De Nantes. Universite De nantes Institut De Recherche Pour Le Development France. Bogor. 36-46.

Lubis, E. 1989. Le organization et l'amenagement des port de peche indonesiens-comparaison avec l'organisation et l'amenagement des port de peche Francais set Europeens. Disertasi Doktor. Universite de Nantes. France.

Lubis, E. 2006. Pengantar Pelabuhan Perikanan (Bahan Kuliah m.a Pelabuhan Perikanan). Ed Ketiga. Fakultas Perikanan dan IImu Kelautan. Institut Pertanian Bogor. Bogor.

Murdiyanto, B. 2003. Pelabuhan Perikanan: Fungsi, Fasilitas, Panduan Operasional, Antrian Kapal. Fakultas Perikanan dan IImu Kelautan. Institut Pertanian Bogor. Bogor. 142 pp.

Mahyuddin, B. 2007. Pola pengembangan pelabuhan perikanan dengan konsep triptique portuaire: Kasus Pelabuhan Perikanan Nusantara Pelabuhan Ratu. Disertasi Dokter. Institut Pertanian Bogor. Bogor.

Nurani, T. W., J. Haluan, S. Sudirman, \& E. Lubis. 2008. Rekayasa sistem pengembangan perikanan tuna di perairan selatan Jawa. Forum Pascasarjana. 31 (2): 79-92.

Suherman, A. 2007. Rekayasa model pengembangan Pelabuhan Perikanan Samudra Cilacap. Disertasi Doktor. Institut Pertanian Bogor. Bogor.

Tamin, O. Z. 2000. Perencanaan dan Pemodelan Transportasi. Institut Teknologi Bandung. Bandung. $633 \mathrm{pp}$. 